\title{
Degeneration And Vacuolation
}

National Cancer Institute

\section{Source}

National Cancer Institute. Degeneration And Vacuolation. NCI Thesaurus. Code C161563.

A finding that generally has features of degeneration and vacuolation. 